\title{
AN INVESTIGATION OF TOURISM MOTIVATION AND TOURIST ATTRACTION OF TOURISTS TO BALI
}

\author{
Christimulia Purnama Trimurti ${ }^{1^{*}}$, I Gusti Bagus Rai Utama ${ }^{2}$ \\ ${ }^{1,2}$ Universitas Dhyana Pura, Indonesia \\ *Corresponding author, Email: christimulia@gmail.com; igustibagusraiutama@gmail.com²
}

\begin{abstract}
The purpose of this study was to investigate the motivation of tourists to travel to Bali. This study used a sample with 213 respondents. The analytical tool used is factor analysis with SPSS version 24 . The results of the study found two tourism motivation for tourists to vacation in Bali, namely by 'Traveling \& Relax' and 'Health'. We also found the results of research on the tourist attraction of tourists on vacation in Bali, namely 'Government and Private Sector', 'Public Service', 'Bali nature and culture' and 'holiday and shopping'. This study has limitations, namely not looking for a relationship between push and pull motivation of tourists to Bali.
\end{abstract}

Keywords: Push motivation, pull motivation, tourists, investigation, motivation.

\section{Introduction}

Within five years there was an increase in tourist arrivals coming to Bali, which were $3,278,598$ in 2013, increasing to 5,697,739 in 2017 (BPS, 2018). The growth of tourists from Europe (45.44\%) dominates tourist visits to Bali, then the growth of tourists from Asia (19.23\%) in second place, and growth of tourists from America (3.57\%) in third place (BPS, 2018). The foreign exchange contribution from the tourism sector has increased since 2015 from US \$ 12.2 billion, 2016 to US \$ 13.6 billion and 2017 rose again to US $\$ 15$ billion (www.bali-travelnews. com). According to the World Travel \& Tourism Council (WTTC) Indonesian Tourism is the $9^{\text {th }}$ fastest in the world, number 3 in Asia and number 1 in the Southeast Asia region (www.bali-travelnews.com). In 2018, Trip Advisor ranked first for Bali as the best tourist destination of the 25 best destinations in the world. Bali which is also often called the Island of the Gods is always interesting to visit because of the many hotel accommodations, unique tourist destinations, natural beauty that is still very well maintained, as well as the beach is always a magnet for those who want to vacation (Alvionitasari \& Wijanarko, 2018).

Tourism certainly is a highly sensitive and vulnerable activity and it is not without reason that tourists have been described as 'shy birds', who can be scared off by any number of real or perceived threats to safety, health and property, or financial wellbeing. Tourism shares with recreation generally, attributes of voluntary, discretionary behavior. People are free to choose to become tourists and to decide location, timing, duration, mode of travel, activities and costs to be incurred. Any one of these attributes may be modified or dispensed with by unforeseen or uncontrollable factors. Moreover, the process of choice is imperceptibly influenced by pervasive adjustments to lifestyle, social mores, traditions and culture. The more environmentally aware tourist of the future may well opt for, and even demand, evidence of a commitment to sustainable forms of tourism (Wahab \& Pigram, 1997).

Some researchers reveal different things about tourism motivation. The main three tourism motivation were (1) 'To travel to a country that I have not visited before', (2) 'To see something different that I don't normally see - something new and exciting', and (3) 'To experience cultures that are different from mine', while the main three tourist attraction included: (1) 'Safety and Security', (2) 'Weather', and (3) 'Cultural and historical places' (Tawil \& Tamimi, 2013). The three categories for tourist motivation were affordability, safety and time (Ratthinan \& Selamat, 2017) Factors influence young people when choosing a city destination are partying and having fun, accessibility to destination info, easy and cheap travel organization, outdoor activities, socializing with the local people, good shopping places and exploring the unknown (Tomić, Kovačević, Berber, \& Milić, 2014). The most important tourism motivation is "education about culture, history, and the heritage (Karamehmedović, 2018). Destination's competitive advantage and image is important for tourist motivation (Mohammad \& Som, 2010). Domestic sport tourists were more significantly motivated by intellectual, social, stimulus-avoidance and competence mastery motives than international sport tourists (Dolinting, Yusof, \& Chee, 2015). The difference in tourism motivation is interesting to study in Bali. 
Each tourist attraction has a different attraction. Tourist attraction were accessibility, trustworthiness and influence (Ratthinan \& Selamat, 2017). Tourist attraction by nature as a product (Reihanian, Hin, Kahrom, Binti Mahmood, \& Porshokouh, 2015). While the three segments regarding tourist attraction were labeled as 'Weather, Safety, and Cleanliness', ' Cultural \& historical attractions' and 'Travel arrangements \& Convenience'. (Tawil \& Tamimi, 2013). Gender, marital status had not a significant influence on tourist motivation and tourist attraction. (Reihanian et al., 2015). The age, monthly income and marital status travelers affect their travel behavior especially in the duration of their trip (Seyidov \& Adomaitiene, 2016). Tourist motivation and tourist attraction had directly positive influences on tourists return intention (Khuong \& Ha, 2014). Policy and managerial implications for tourist attractions and support services in tourism (Mohammad \& Som, 2010; Phau, Lee, \& Quintal, 2013). The difference in tourist attractions is an interesting thing to study in Bali.

\section{Result and Discussion}

Demographic profile of respondents. Table 1 outlines the demographic profile of respondents. Most of the respondents were male $(57.7 \%)$, Under 50 years old (78.4\%) age group, Nederland (18.8\%), above second arrival (49.3\%).

Table 1

Description of Survey Respondents $(N=213)$

\begin{tabular}{lclc}
\hline $\begin{array}{c}\text { Sosiodemographic } \\
\text { Variable }\end{array}$ & $\begin{array}{c}\text { Percen- } \\
\text { tage }\end{array}$ & $\begin{array}{l}\text { Sosiodemographic } \\
\text { Variable }\end{array}$ & $\begin{array}{c}\text { Percen- } \\
\text { tage }\end{array}$ \\
\hline Country & & Country \\
Argentina & 1 & Russia & 4 \\
Australia & 6 & New Zealand & 2 \\
Austria & 1 & Slovakia & 1 \\
Nederland & 19 & Slovenia & 1 \\
Belarusian & 1 & Spanyol & 2 \\
Belgia & 3 & Sweden & 4 \\
Brazil & 1 & Swiss & 6 \\
Denmark & 1 & UK & 4 \\
Finland & 1 & Ukraine & 1 \\
Hongkong & 1 & USA & 10 \\
Ireland & 1 & Portugal & 1 \\
Italy & 7 & French & 8 \\
Germany & 13 & Norwegia & 1 \\
Canada & 3 & Luxembourg & 1 \\
Gender & & Age & \\
Male & 58 & Under 50 years old & 78 \\
Female & 42 & Above 50 years old & 22 \\
Frequency of Arrival & & & \\
First Arrival & 31 & & \\
Second Arrival & 20 & & \\
Above Second & 49 & & \\
Arrival & & & \\
\hline
\end{tabular}

\section{Factor Analysis of the Tourism motivation}

The MSA value for the six measured variables is greater than 0.5 , which means that the sampling process is sufficient. In Table 3, the first eigenvalue factor value is 35.905 and the second eigenvalue factor value is 21.125. A principal component factor analysis with varimax rotation was performed to analyze the underlying dimensions for the tourism motivation. The eight push items revealed two factors with eigenvalues $>1$ (Table 2). These factors explained $65.8 \%$ of the variance and were labelled 'Traveling \& Relax' and 'Health'. Factor loadings for the eight push items ranged from 0.665 to 0.818 . The first and second factors yielded reliability as close to the standard of 0.7 recommended by Nunally (1978) in Phau et al. (2013).

Table 2

Total Variance Explained

\begin{tabular}{cccc}
\hline \multirow{2}{*}{ Component } & \multicolumn{3}{c}{ Initial Eigenvalues } \\
\cline { 2 - 4 } & Total & \% of Variance & Cumulative \% \\
\hline 1 & 2.365 & 39.424 & 39.424 \\
2 & 1.583 & 26.377 & 65.801 \\
3 & .696 & 11.608 & 77.409 \\
4 & .596 & 9.928 & 87.338 \\
5 & .486 & 8.092 & 95.430 \\
6 & .274 & 4.570 & 100.000 \\
\hline \multirow{2}{*}{ Component } & \multicolumn{2}{c}{ Extraction Sums of Squared Loadings } \\
\cline { 2 - 4 } & Total & \% of Variance & Cumulative \% \\
\hline 1 & 2.365 & 39.424 & 39.424 \\
2 & 1.583 & 26.377 & 65.801 \\
\hline
\end{tabular}

\section{Factor Analysis of the Tourist attraction}

The MSA value for the 15 measured variables is greater than 0.5 , which means that the sampling process is sufficient. In Table 3, the first eigenvalue factor value is 39.702 , the second eigenvalue factor value is 13.285 , the third eigenvalue factor value is 8.486 , the fourth eigenvalue factor value is 6.747 . A principal component factor analysis with varimax rotation was performed to analyze the underlying dimensions for the tourist attraction. The fifteenth pull items revealed four factors with eigenvalues $>1$ (Table 3). These factors explained $68,22 \%$ of the variance and were labelled 'Government and Private Sector', 'Public Service', 'Bali nature and culture' and 'holiday and shopping'. Factor loadings for the fifteenth pull items ranged from 0.538 to 0.890 . The first until fourth factors yielded reliability as close to the standard of 0.7 recommended by Nunally (1978) in Phau et al. (2013). 
Table 3

Total Variance Explained

\begin{tabular}{cccc}
\hline \multirow{2}{*}{ Component } & \multicolumn{3}{c}{ Initial Eigenvalues } \\
\cline { 2 - 4 } & Total & \% of Variance & Cumulative \% \\
\hline 1 & 5.955 & 39.702 & 39.702 \\
2 & 1.993 & 13.285 & 52.987 \\
3 & 1.273 & 8.486 & 61.474 \\
4 & 1.012 & 6.747 & 68.221 \\
5 & 0.864 & 5.760 & 73.981 \\
6 & 0.794 & 5.291 & 79.272 \\
7 & 0.624 & 4.158 & 83.430 \\
8 & 0.516 & 3.441 & 86.871 \\
9 & 0.404 & 2.693 & 89.564 \\
10 & 0.385 & 2.570 & 92.134 \\
11 & 0.336 & 2.242 & 94.376 \\
12 & 0.323 & 2.154 & 96.530 \\
13 & 0.200 & 1.331 & 97.861 \\
14 & 0.199 & 1.326 & 99.188 \\
15 & 0.122 & 0.812 & 100.000 \\
\hline \multirow{2}{*}{ Component } & Extraction Sums of Squared Loadings \\
\cline { 2 - 4 } & Total & \% of Variance & Cumulative \% \\
\hline 1 & 5.955 & 39.702 & 39.702 \\
2 & 1.993 & 13.285 & 52.987 \\
3 & 1.273 & 8.486 & 61.474 \\
4 & 1.012 & 6.747 & 68.221 \\
\hline
\end{tabular}

\section{Discussion}

The results of this study indicate that foreign tourists visiting Bali are encouraged by 'Traveling \& Relax' and 'Health'. The desire of tourists for 'Traveling \& Relax' and 'Health' must be the government's concern to be able to provide maximum value on both of these factors. The results showed 4 driving factors for tourists coming to Bali, namely 'Government and Private Sector', 'Public Service', 'Bali's nature and culture' and 'holidays and shopping'.

Table 4

Rotated Component Matrix

\begin{tabular}{lcc}
\hline & \multicolumn{2}{c}{ Component } \\
\cline { 2 - 3 } & 1 & 2 \\
\hline Take a break and relax & 0.698 & -0.245 \\
New places & 0.693 & -0.305 \\
Knowledge and experience & 0.753 & -0.195 \\
Get out of the routine & 0.665 & -0.278 \\
Health and fitness & 0.457 & 0.803 \\
Physical training & 0.425 & 0.818 \\
\hline
\end{tabular}

Tourists must feel a pleasant trip by seeing different places while relaxing in Bali. Vacation trips in Bali must be able to provide beautiful memories full of meaning in their minds and hearts. Every place visited by tourists must be able to answer their curiosity about the area so that they can get to know Bali more closely. Foreign tourists want to have a holiday experience in Bali even though information about Bali can be obtained easily via the internet.

All stakeholders maintain good cooperation to provide comfort to tourists. Bali is obliged to maintain its reputation as one of the world's best places to vacation through improving the quality of tourism objects, improving the quality of services, and improving tourism support. Good cooperation between the government and the private sector is important in maintaining the quality of tourism.

Population density in Bali is very vulnerable to environmental damage. Bali needs to improve the concept of environment-based development to maintain the tourist attraction which is a factor driving tourists to Bali. The uniqueness of Bali in Balinese culture and art products is an important tourist attraction that must be maintained.

The results of this study have some similarities with the results of research conducted by Reihanian $e t$ al. (2015), Tomić et al. (2014), and Tawil and Tamimi (2013).

The results of this study are interesting because they are different from the results of research in the world. The difference is 'Government and Private Sector', 'Public Service' become a tourist attraction in Bali.

Table 5

Rotated Component Matrix

\begin{tabular}{lrccc}
\hline & \multicolumn{4}{c}{ Component } \\
\cline { 2 - 5 } & 1 & 2 & 3 & \multicolumn{1}{c}{4} \\
\hline Balinese history & 0.021 & 0.410 & 0.754 & 0.170 \\
Balinese culture & 0.123 & 0.201 & 0.890 & 0.099 \\
Bali Nature & 0.107 & 0.086 & 0.868 & 0.056 \\
Prices in Bali & 0.328 & 0.264 & 0.263 & 0.596 \\
Even and festival & -0.010 & 0.741 & 0.191 & 0.302 \\
Vacation or free time & 0.081 & 0.339 & 0.014 & 0.766 \\
Transportation & 0.356 & 0.575 & 0.167 & 0.199 \\
Distance from country & 0.187 & 0.538 & 0.349 & 0.240 \\
of origin & & & & \\
Food and Drink & 0.088 & 0.002 & 0.525 & 0.567 \\
Facilities and services & 0.260 & 0.685 & 0.023 & 0.287 \\
Health and insurances & 0.365 & 0.732 & 0.244 & -0.190 \\
facilities & & & & \\
Immigration services & 0.765 & 0.277 & 0.123 & -0.023 \\
and procedures & & & & \\
\hline
\end{tabular}

\section{Conclusion}

The results of the study found two tourist motivation vacation in Bali, namely by 'Traveling \& Relax' and 'Health'. We also found the results of research on the tourist attraction of tourists on vacation in Bali, namely 'Government and Private Sector', 'Public Service', 'Bali nature and culture' and 'holiday and shopping'. 
The result of this research will be more perfect if it is continued by another study to find the impact of tourist motivation and tourist attraction on tourist satisfaction.

\section{Acknowledgement}

This research supported by The Ministry of Research and Higher Education of the Republic of Indonesia, through the Fundamental Research Grant for the fiscal year 2019-2020 and Dhyana Pura University, who has giving the opportunity to conduct research. We would like also to thank to our research helper who gathered data on field survey.

\section{References}

Alvionitasari, R., \& Wijanarko, T. (2018). Kalahkan Paris, Bali peringkat 1 destinasi wisata terbaik dunia. Tempo.co. Retrieved fromhttps://travel. tempo.co/read/1067443/kalahkan-paris-baliperingkat-1-des tinasi-wisata-terbaik dunia/full $\&$ view $=0$.

BPS. (2018). Provinsi Bali dalam angka 2018. Bali: Badan Pusat Statistik Provinsi Bali.

Dolinting, E. E., Yusof, A., \& Chee, C. S. (2015). Application of push \& pull theory in island sport tourism: A study of Sipadan Island, Sabah. Journal of Physical Education and Sport, 15(2), 295-304.

Karamehmedović, D. (2018). "Push-pull" analysis towards creating holistic marketing of the cultural heritage tourism destination: The case study of Dubrovnik. Ekon. Misao I Praksa Dbk. GOD XXVII. BR, 1, 29-51.

Khuong, M. N., \& Ha, H. T. T. (2014). The influences of push and pull factors on the international leisure tourists' return intention to Ho Chi Minh City, Vietnam - A mediation analysis of destination satisfaction. International Journal of Trade, Economics and Finance, 5(6), 490-496.
Mohammad, B. A. M. A., \& Som, A. P. M. (2010). An analysis of push and pull travel motivations of foreign tourists to Jordan. International Journal of Business and Management, 5(12), $41-50$.

Phau, I., Lee, S., \& Quintal, V. (2013). An investigation of push and pull motivations of visitors to private parks: The case of Araluen Botanic Park. Journal of Vacation Marketing, 19(3), 269-284.

Ratthinan, S. P., \& Selamat, N. H. (2017). Understanding the push and pull motivational factors of technology usage for traveling among women students in USM, Penang. Journal of Information System and Technology Management, 2(4), 52-63.

Reihanian, A., Hin, T. W., Kahrom, E., Binti Mahmood, N. Z., \& Porshokouh, A. B. (2015). An examination of the effects of push and pull factors on Iranian national parks: Boujagh National Park, Iran. Caspian Journal Environmental Sciences, 13(3), 197-206.

Seyidov, J., \& Adomaitiene, R. (2016). Factors influencing local tourists' decision-making on choosing a destination: A case of Azerbaijan. Ekonomika, 95(3), 112-127.

Tawil, R. F., \& Tamimi, A. M. A. (2013). Understanding Chinese tourists' travel motivations: Investigating the perceptions of Jordan held by Chinese Tourists. International Journal of Business and Social Science, 4(17-Special Issue), 164-170.

Tomić, N., Kovačević, B., Berber, N., \& Milić, N. (2014). Factors influencing the motivation of young people when choosing a city destination in Europe - A case study from Esbjerg (Denmark). European Researcher, 69(2-2), 414-428.

Wahab, S., \& Pigram, J. J. (1997). Tourism, development and growth: The challenge of sustainability. London, UK: Routledge. 